\title{
EDITORIAL
}

\section{National or Regional Law Library Organizations and Their Publications}

$\mathrm{D}$ ESPITE FREQUENT references in modern literature to the vanishing breed of librarians, professional organizations of law librarians keep on springing up around the world. Some, like the venerable American Association of Law Libraries, have more members (in excess of 5100 ) than all law librarians put together in the rest of the world. Most organizations are relatively small. An interesting characteristic of practically all of them is the enthusiasm and energy exhibited by their members. Most of the organizations regularly publish journals or newsletters. Some manage fairly regularly to produce two or more periodical publications.

What follows is a list of national or regional law library organizations and the journals, newsletters or other periodical series they publish. The list is by no means complete. We hope to update and expand it in the future. Readers are invited to contribute additional information as well as send us corrections and comments. We shall incorporate them in future installments on this topic.

American Association of Law Libraries (AALL)

Established in I906.

Publishes:

Law Library Journal (quarterly, publication began in 1908)

AALL Newsletter (monthly except for January and August)

AALL Directory and Handbook (annual)

Biographical Directory of the American Association of Law Libraries (irregular)

Index to Foreign Legal Periodicals (quarterly with annual contributions)

AALL also sponsors the publication of several series on legal bibliography, legal research and law librarianship.

Individual special interest sections and regional or local chapters of the American Association of Law Libraries publish their own newsletters. 
Arbeitsgemeinschaft für juristisches Bibliotheks-und Dokumentationswesen (AjBD)_Association for Law Librarianship and Documentation in German-speaking countries (Austria, Germany, Switzerland).

Established in 1971 .

Publishes:

Recht, Bibliothek, Documentation (the official journal of the AjBD, published three times a year)

Arbeitshefte der AjBD (irregular)

Australian Law Librarianship Group (ALLG)

Publishes:

Australian Law Librarian (semiannual since 1993, previously ALLG Newsletter)

Association Belge des bibliothecaires et des documentalistes juridiques (Belgium) Established r99..

Publishes:

JBDJ Newsletter (No. I appeared in 1992).

British-Irish Association of Law Librarians (BIALL)

Established 1969.

Publishes:

Law Librarian (quarterly)

Canadian Association of Law Libraries/Association Canadienne des bibliotheques de droit

Founded as a chapter of the American Association of Law Libraries in 1963; became an independent association in $197 \mathrm{I}$.

Publishes:

Canadian Law Libraries/Bibliotheques de droit canadiennes (five times a year)

Caribbean Association of Law Libraries

Established 1984 .

Publishes:

Caribbean Journal of Legal Information (twice a year)

Groep Juridische Bibliotecarissen, Documentalisten en Literatuuronderzoekers (GJB) - The Netherlands Law Library Association.

Established in 1960. 
Publishes:

De Juridische Bibliothekaris (semiannual)

Publikaties van de Groep Jurisdische Bibliothecarissen (irregular)

New Zealand Law Librarian's Group

Officially established ig89.

Publishes:

New Zealand Law Librarians' Group Newsletter (every two or three months)

Organization of South African Law Libraries/Organisasie van Suid-Afrikaanse Regsbiblioteke (OSALL/OSAR)

Publishes:

OSALL/OSAR Newsletter (frequency not known)

Organizations of law librarians also are known to exist in Nigeria and in Southeast Asian countries. It is not known whether they publish newsletters. More information about them is required.

There is a Scottish Law Librarians' Group, but no information is available about its publications, if any.

In 1992 a group of dedicated law librarians from the Commonwealth countries began to publish the Commonwealth Law Librarian. It appears semiannually and focuses on matters of interest to law librarians in the United Kingdom, Australia, New Zealand, Canada, Caribbean and the anglophonic countries of Africa and Asia.

Has anything been omitted or inaccurately reported? Please, send information on regional or national law library associations and their publications to:

IJLI Editorial Office

P.O. Box 31545

St. Louis, MO 63131-0545

U.S.A. 